Historic, Archive Document

Do not assume content reflects current scientific knowledge, policies, or practices. 


RUECWDT WWD $x \operatorname{DtC} 13921 *$

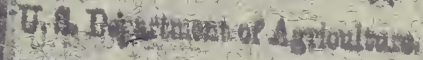

\title{
1922
}

\section{RICHARD LOHRMANN}

THE WEST END NURSERY

19 CENTER STREET

\author{
SAN RAFAEL. CALIFORNIA
}





\section{Dahlias \\ 1922}

RICHARD LOHRMANN

THE WEST END NURSERY 119 CENTER STREET 


\section{To My Customers:-}

$\infty$

The following list of Dahlias comprises the cream of numerous varieties originated in California. They have been selected for their superiority in purity of color, perfection of form, length of stem, continuous blooming, etc.

Referring to the description in this list, there ought to be made a certain allowance for variation, caused by different soils and climatic conditions.

Prices are for divided field grown roots, pot grown bulbs, or green plants after May 1st, either kind will give equally good resilts, in fact, well-rooted plants out of $2 \frac{1}{2}$ pots are often preferred by experienced growers. I usually ship al! orders atter April 1st; if wanted earlier kindly state so, when ordering.

Small orders of Dahlia tubers will be sent by mail, larger orders by express.

Terms:-Cash with order, or in advance of shipment; no C. O. D. orders accepted, unless at least $20 \%$ of amount is sent with order. Postage prepaid on all retail orders when payment in full is made, at time of ordering.

I warrant all roots and plants, to be healthy, and true to label, but having no control over them, after delivery, I do not guarantee them to live and thrive, nor will I replace them. except any plant should prove untrue to name; but in no case will I be liable for any sum greater than the original purchase price.

My customers are requested to notify me immediately of any error, that may have occurred in filling their order, so that the same may be rectified, as I desire to give satisfaction to all, who favor me with their order.

As it is practically impossible to classify every variety of Dahlia, I have arranged them in alphabetical order, and used the rollowing abbreviations:

C-Cactus: H. C. - Hybrid Cactus: D-Decorative; Sh-Show: H. Sh.-Hybrid Show: Pae-Paeonia flowering; F-Fancy. 


\section{MEDALS:}

AWARDED FOR GROWING EXHIBITS OF

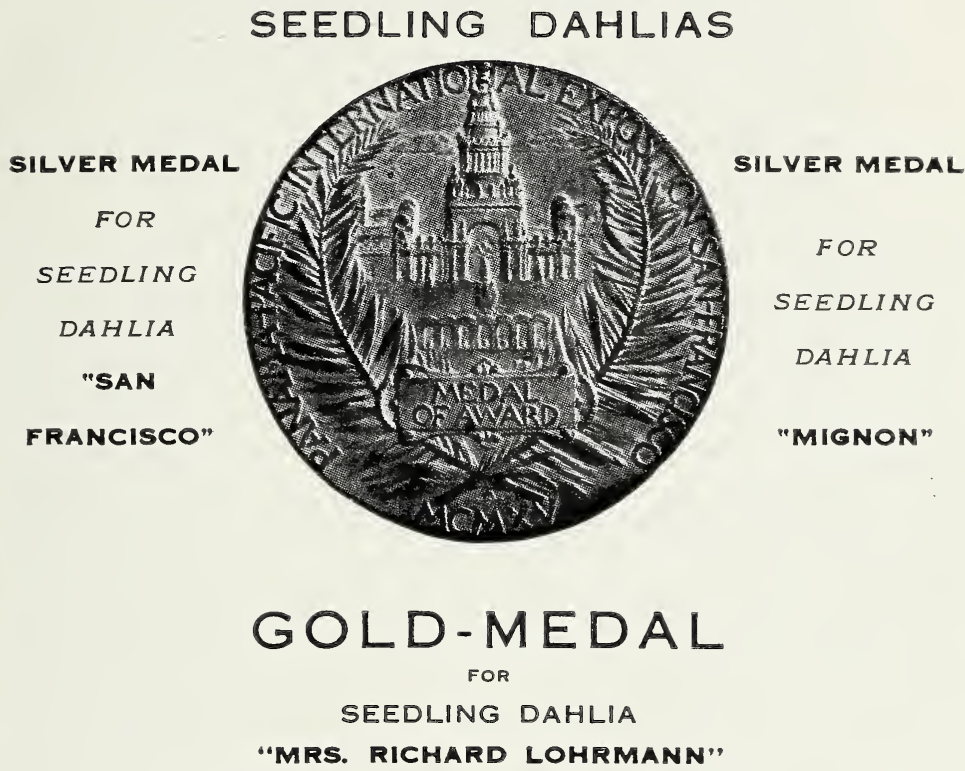

(THE ONLY GOLD-MEDAL AWARDED FOR A SEEDLING)

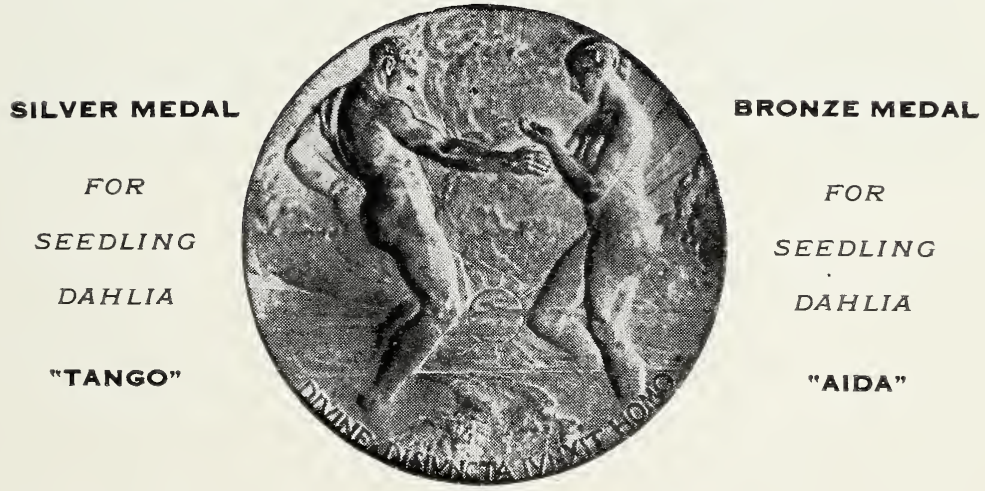

A T

PANAMA PACIFIC INTERNATIONAL EXPOSITION SAN FRANCISCO, CALIFORNIA, 1915 


\section{GOLD MEDAL}

\section{AWARDED FOR A GROWING EXHIBIT OF 36 VARIETIES OF DAHLIAS}

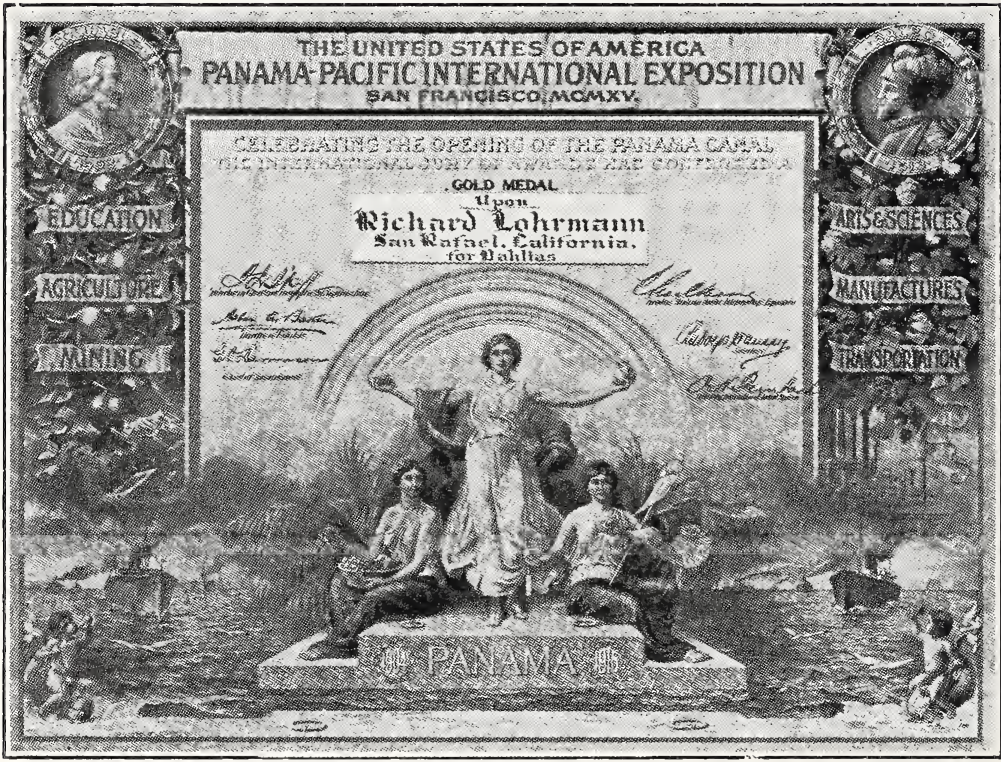

\section{A RECENT AWARD \\ The T. A. BURNS TROPHY CUP \\ $\infty$}

For the best 12 varieties of California origin, at the Palace Hotel Show, held by the Dahlia Society of California, September 15th-17th, 1921. 


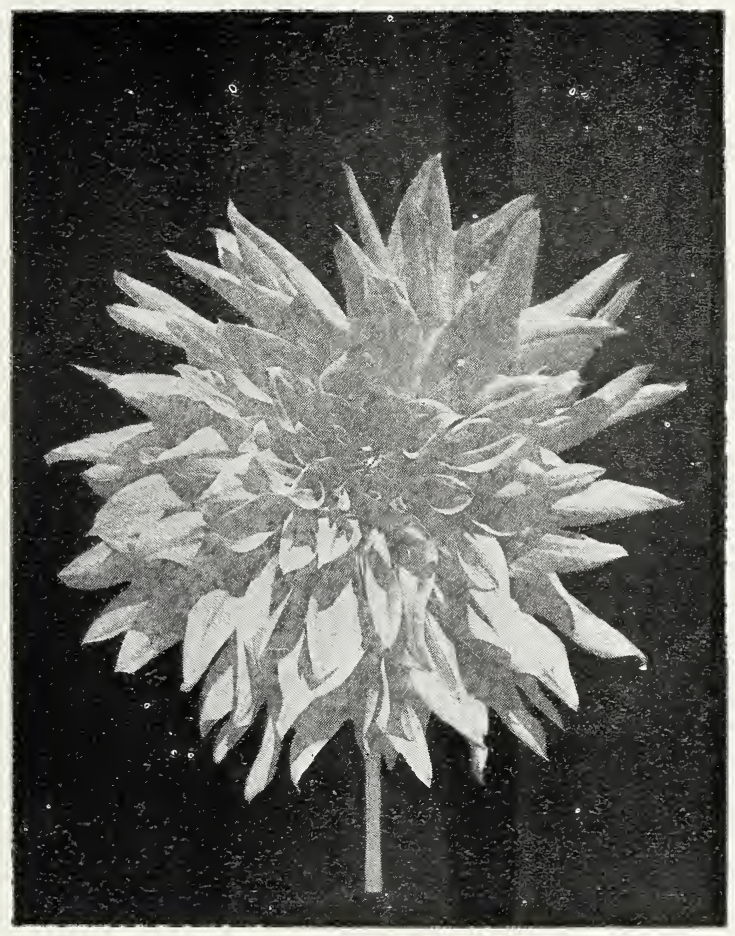

"S E N O R I T A"

My new introduction of a giant decorative Dahlia was awarded a Silver Medal in the 3-year-o!d Seedling Class, at the Palace Hotel Show in San Francisco; also First Prize in the same class at the California Horticultural Exposition (growing exhibit) in Los Angeles. Each bloom, held absolutely erect on extra strong stem, measures from 9-10 inches across; of perfect form until late in the season. A rich velvety crimson, just the color to match the dark Spanish type of the "Senoritas" of the days of old. Price $\$ 5.00$ each 


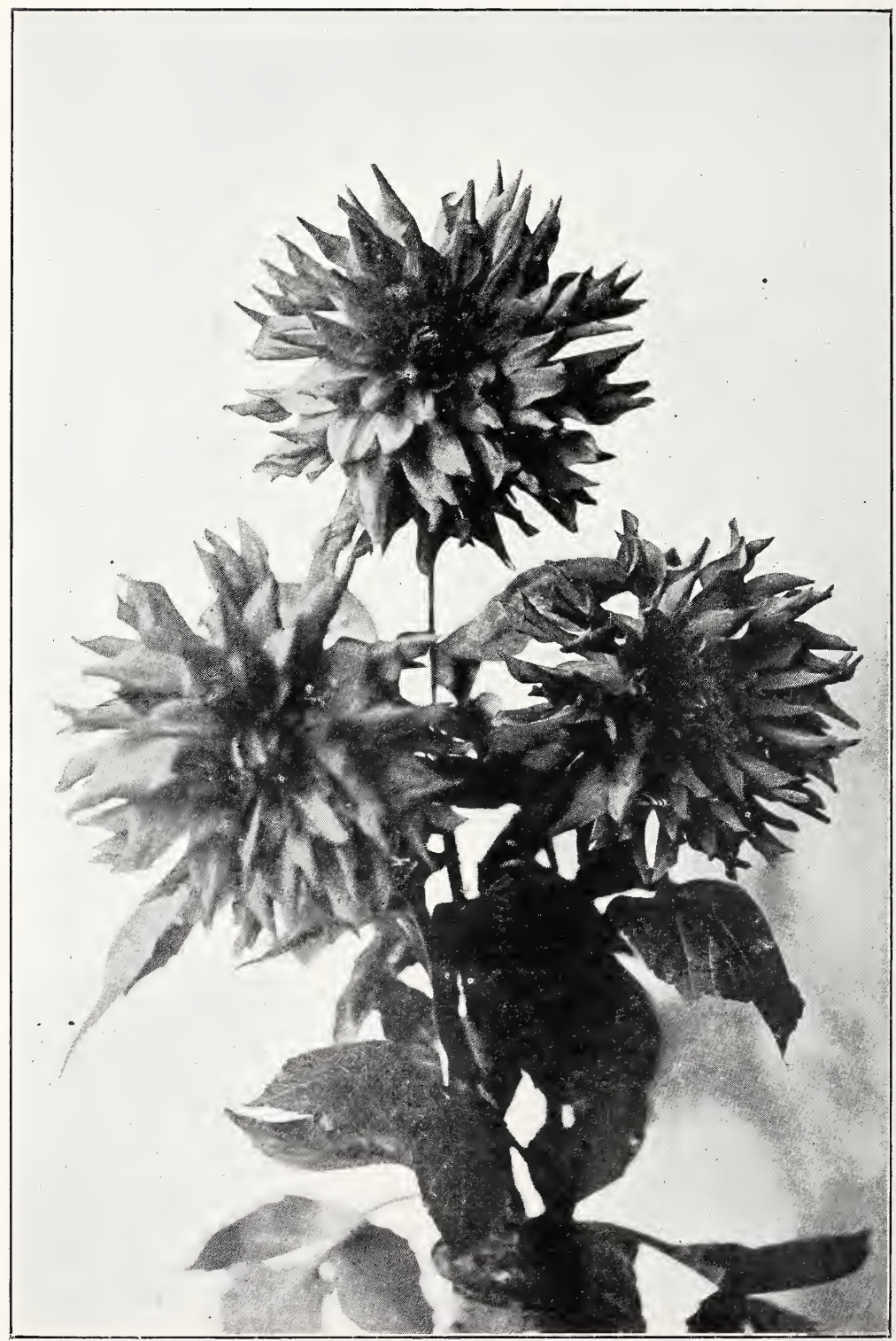




\section{CALIFORNIA DAHLIAS}

$\infty$

\section{MY OWN INTRODUCTIONS}

I take pleasure in offering a collection of Dahlias of my own raising to my customers. A number of these varieties were planted and exhibited at the Panama-Pacific International Exposition in San Francisco. They have proven valuable additions to the list of Dahlias and I can recommend them to every lover of these gorgeous flowers.

\section{AIDA-D.}

Dark maroon, large perfect flowers on rigid upright stems, carried high above the foliage; awarded a Bronze Medal at the Panama-Pacific International Exposition.

Price 50cts. each

\section{ELSA-Pae}

Fluffy, white flowers, yellow center, large size and showing high above the foliage; unsurpassed as a cut flower. The best white Paecnia Dahlia, its sterling qualities are appreciated more every year; demand always larger than the supply. Price $75 \mathrm{cts}$. each

\section{GIRL OF THE GOLDEN WEST-C. Pae.}

Light yellow, tinged and tipped with red; long twisted petals, a very showy, artistic flower.

Price 50cts each

\section{LA FAVORITA}

A splendid new Hybrid Cactus variety, unexcelled in form. type, growing and flowering qualities: distinct in color, which is a beautiful brilliant salmon; shading from a dark reddis! salmon in the center to salmon-pink at the twisted points. Form perfect, showing a full center even late in the season. Each bloom carried on a strong stem.

A first-class cutflower variety, which has taken its place alongside the very best Dahlias of recent introductions, and a prize-winner at every show.

Awarded First Prize for a vase of 12 blooms at the Oakland Dahlia Show in 1918, and First Prize for a vase of the best established Dahlias, California Origin, at the Palace Hotel Show in San Francisco, 1919. Price $\$ 2.00$ eacis 


\section{THE PANAMA PACIFIC EXPOSITION \\ GOLD MEDAL DAHLIA}

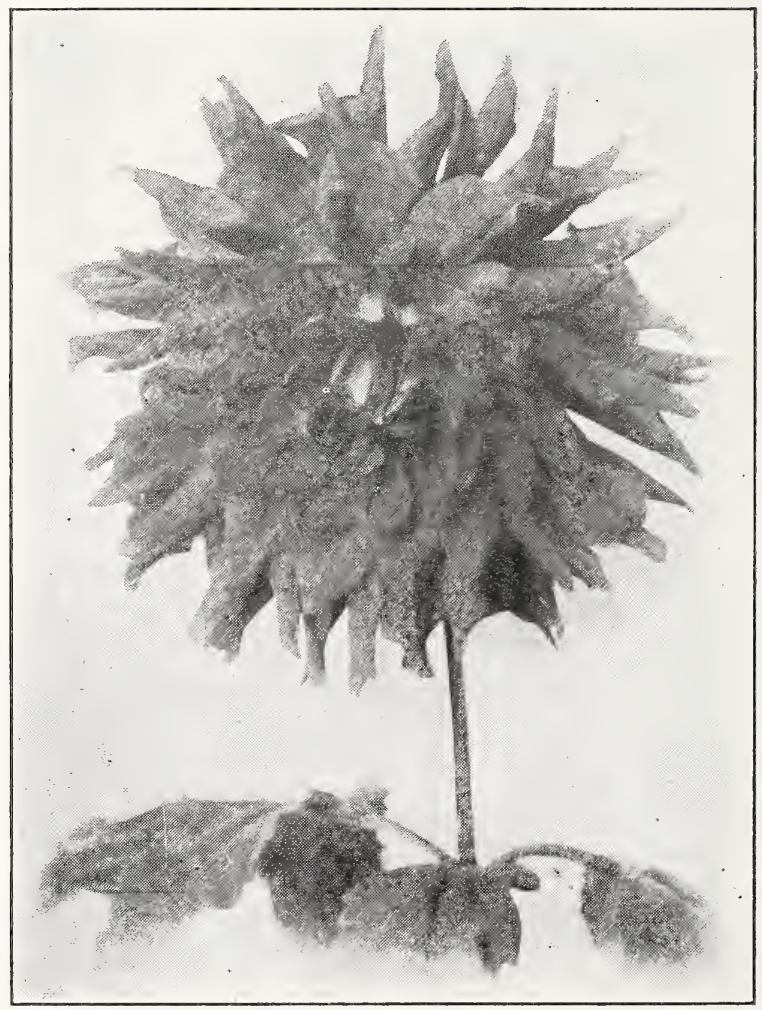

MRS. RICHARD LOHRMANN

A pure golden yellow Hybrid Cactus Dahlia of immense size, broad, curly petals; flowers high above the foliage; on long upright stems; excellent cut flower and very floriferous, the best yellow Dahlia to date. Awarded Gold Medal for the best Seedling Dahlia, growing at the Panama-Pacific International Exposition in San Francisco, 1915.

Price $\$ 1.50$ each 


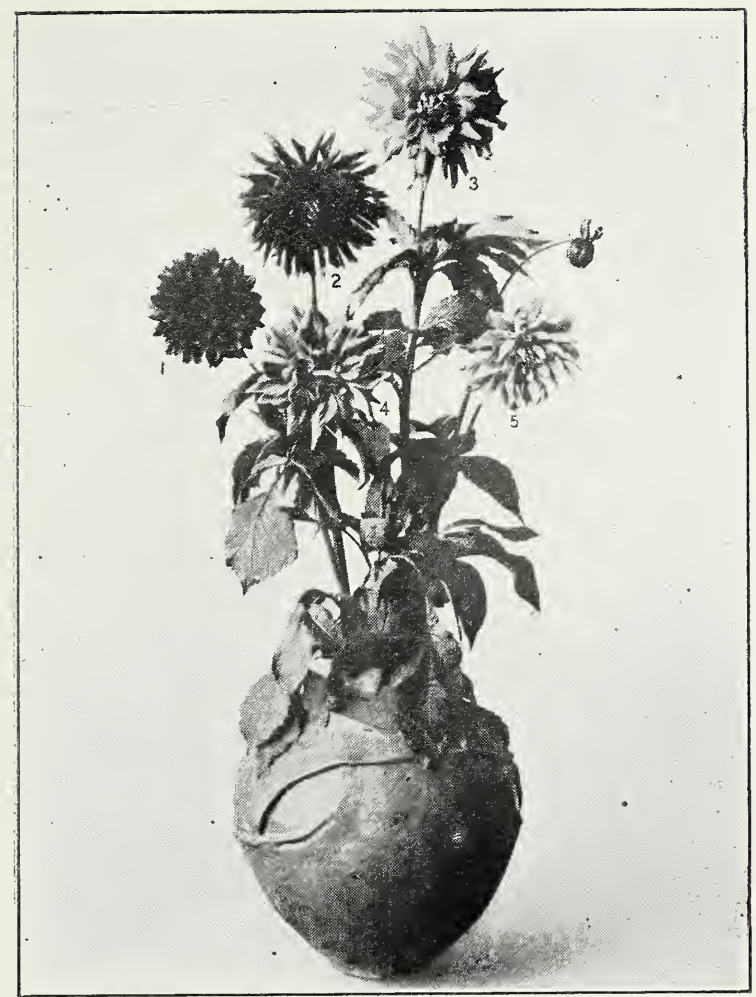

Prize-winners at the Panama-Pacific Exposition in San Francisco, 1915. 1-Aida. 2-San Francisco. 3-Mrs. R. Lohrmann. 4-Tango. 5-Mignon.

\section{NATOMA-Pae.}

A new variety of true Paeony type, very large flowers: color scarlet orange suffused with yellow; base and tips of reach petal a yellowish orange; the blooms in opening are of a darker color, fading to a lighter shade, as they mature. A fine cut-flower variety and good keeper. Price $\$ 1.00$ each

\section{SALOME JANE-H. C.}

Old gold, tinged with red, broad twisted and recurved petals, perfect shaped flowers of immense size, a variety fine for exhibition. Price 75 cts. each 


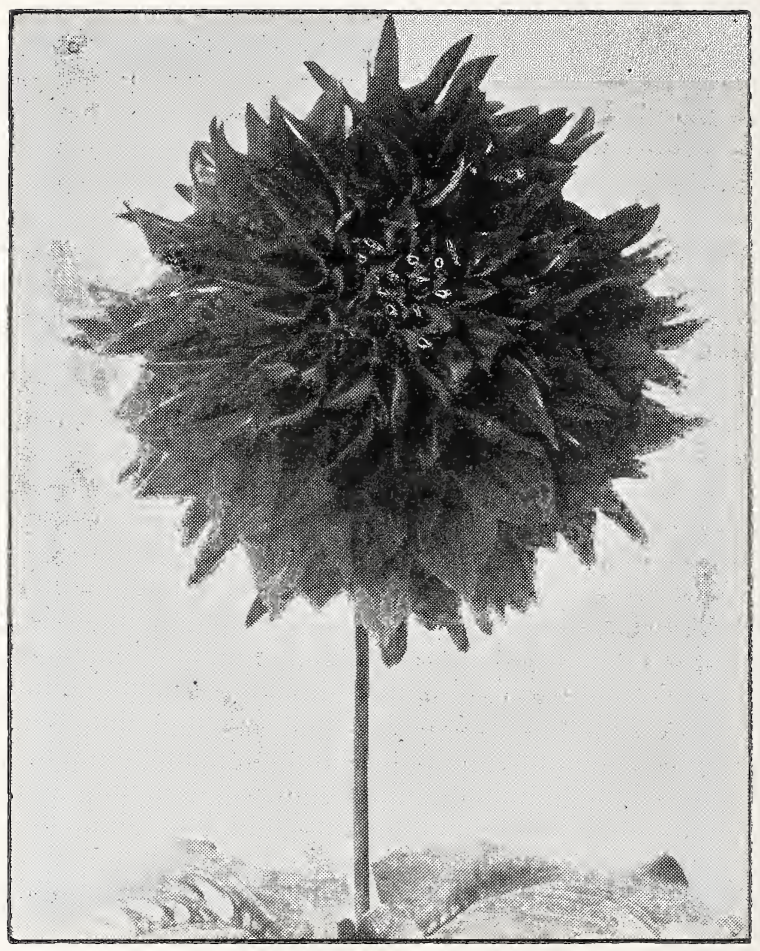

THE PRIDE OF CALIFORNIA

A cross between the famous M. Burgle and "Souvenir Doazon" with the qualities of both parents combined. Color a crimson red, dark full center; huge flowers on long perpendicular stems. Its keeping qualities as a cut-flower and its productiveness cannct be excelled. An American Beauty amongst Dahlias.

Awarded Gold Medal for the best 3-year Seedling at the Palace Show in San Francisco, 1917.

Silver Medal, growing exhibit at the Trial Gardens of the Dahlia Society of California, 191\%.

This variety won first prize for the best vase of red, at the 1920 show of the American Dahlia Society in New York.

Price $\$ 1.00$ each 


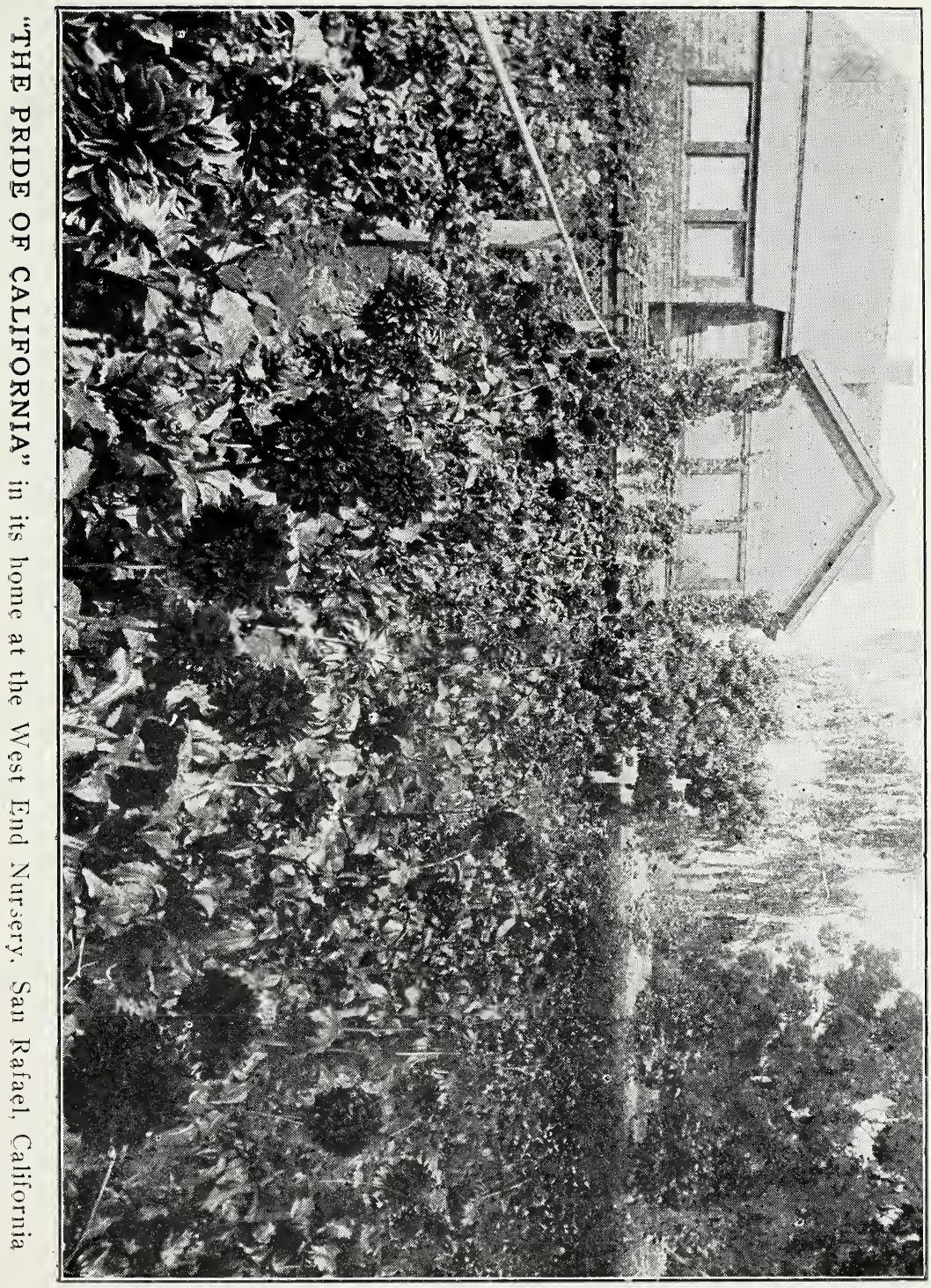




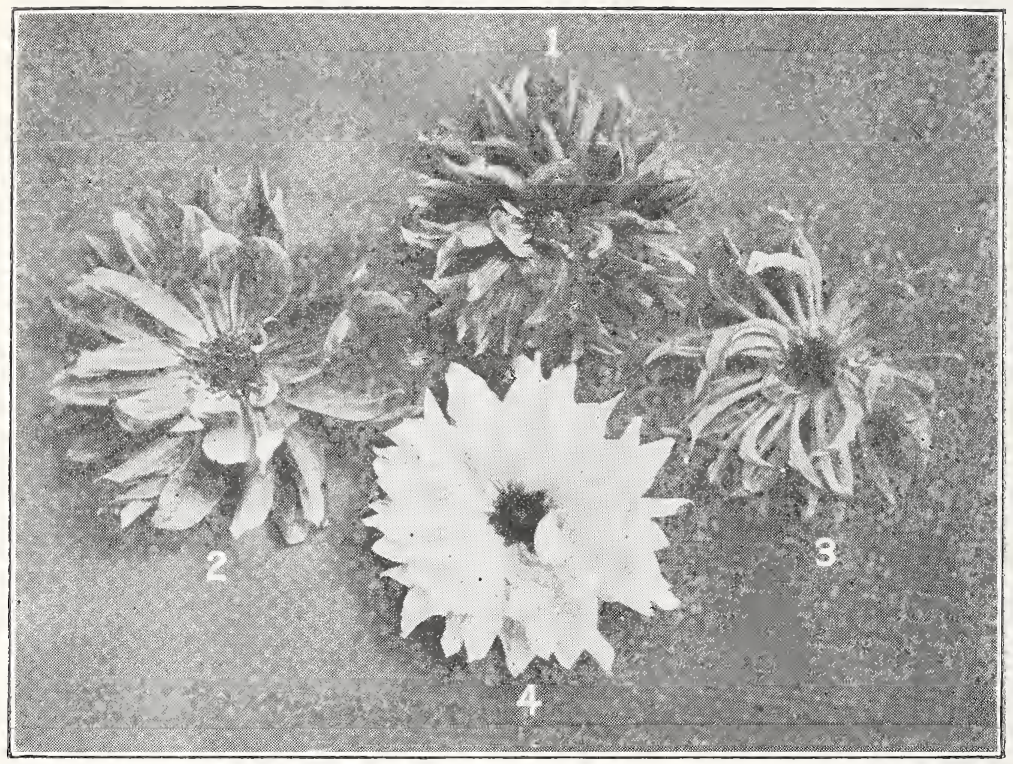

1-Telramund. 2-Natoma. 3-Girl of the Golden West. 4-E1sa.

\section{SAN FRANCISCO-H. C.}

Immense flowers of a reddish bronze, petals broad an twisted, carried on upright rigid stems, high above the foliage: awarded a Silver Medal at the Panama-Pacific International Exposition.

Price 75cts each

\section{TELRAMUND-PaE}

Carmine-red with pink tips; large flowers, well above the foliage.

Price 50cts. each

\section{TANGO-Pae.}

Large salmon colored flowers, prolific bloomer, and a fine cut-flower variety; awarded silver medal at the Panama Pacific International Exposition.

Price 50cts. each 


\section{CALIFORNIA DAHLIAS}

$\infty$

THE BEST INTRODUCTIONS OF OTHER GROWERS DR. H. L. TEVIS-D.

(Pelicano)

A novelty and a star of first magnitude: flowers, nine to eleven inches in diameter, erect on long vigorous stem; color a beautiful shade of salmon rose, suffused with old gold, shading to apricot.

Price $\$ 1.00$ each

\section{GEO WALTERS-H. C. \\ (Carter)}

One of the largest Dahlias ever introduced; very free flowering, a pleasing shade of salmon pink, shading to yellow at the base.

Price 75 cts each

\section{HELEN DURNBAUGH-H. C.}

(Broomall)

Color a pleasing shade of delicate blush; buds open a creamy white, changing to a soft rosy tint, as flower expands, nearing a La France rose color, when fully open. Beautiful form, wiry stem.

Price $\$ 1.00$ each

\section{HELIO-Pae.}

\section{(Diener)}

A deep bright canary yellow, of enormous size; stems very long and wiry; growth strong and healthy; extremely free flowering, the best yellow of the paeony type.

Price $\$ 2.00$ each

\section{JANE SELBY-D. \\ (Bessie Boston)}

Exceptionally large flower of a delicate mauve pink, great substance and beautiful form, on strong stems high above the foliage; a prize winner.

Price $\$ 1.00$ each

MRS. JESSIE SEAL-Pae.

(Gleadell)

A novelty of sterling merit; large salmon rose flowers, on strong stems.

Price $\$ 1.00$ each 


\section{MRS. CARL SALBACH-D.}

(Salbach)

Immense blooms of a lavender pink color, on exceptionally strong stems, a perfect exhibition and cut-flower variety; one of the best of last year's novelties.

Price $\$ 3.00$ each

\section{MRS. F. C. BURNS-D.}

\section{(Burns)}

A shell pink decorative of fine habits, excellent grower and cut-flower variety.

Price $\$ 1.50$ each

\section{MRS. W. E. ESTES-H. C.}

(Estes)

Large, pure, white flowers of fine form on long, upright stems; a profuse bloomer.

Price $\$ 1.50$ eacl

\section{MRS. T. A. MUNROE-H. C.}

(Carter)

A giant flower, color amber, shading to old gold, outer petals tinted brown.

Price 75 cts each

MRS. MABEL B. TAFT-D.

(Bessie Boston)

A novel color of light yellow, suffused with pinkish apricot, lighter in the center and shading deeper towards the outer petals.

Price $\$ 2.00$ eacin

\section{PRINCESS PAT}

\section{(McWirther)}

A beautiful bloom of old rose color, great depth and size, extra strong stem; one of the best of the newer varieties.

Price \$2.00 each

\section{PACIFIC-D.}

(McWinther)

A pleasing variety, color a creamy yellow, orerlaid with pink, good stem and fine form.

Price $50 \mathrm{cts}$ each

\section{RUTH GLEADELL-H. C. (Seal)}

Beautiful large blossom of soft yellow, shading to pink on the outer petals, excellent form and fine stem.

Price $75 \mathrm{cts}$. each 


\section{(Kessing)}

A flaming red with golden tips; large, loose, artistic flower on strong stem.

Price $\$ 1.00$ each

\section{THE EAGLE-H. C. \\ (Burns)}

Sulphur yellow, florets slightly recurved; very large flowers on strong stems.

Price $\$ 1.50$ each

\section{THE GRIZZLY-D. \\ (Burns)}

A dark maroon red of enormous size; on very heavy, strong stems; a vigorous grower and good bloomer; first class exhibition variety.

Price $\$ 2.50$ each

\section{TOM LUNDY -D.}

(Fenton)

Immense blooms of a dark rich crimson, full flowers, but very often reverts to the Paeony type. Price 50cts each

\section{SPECIAL OFFER-NO. 1.}

One each of above eighteen varieties for $\$ 20.00$ postpaid to any place in the United States.

\section{SPECIAL OFFER-NO. 2}

One each of my own introductions, twelve varieties including "Senorita" for $\$ 12.50$, postpaid, sent to any place in the United States.

\section{"INSULINDE"}

A new decorative or Hybrid Cactus Dahlia from Holland. In listing this Dahlia of foreign origin, I am breaking my good or bad intention to confine myself to the growing of California Dahlias only. But I consider "Insulinde" the acme of perfection in a Dahlia. Its color is a rich golden orange, suffused with bronze and apricot shadings. The flowers are carried on the top of the stems, like Chrysanthemum; the broad petals waved and curled in the most artistic fashion.

It received the second prize for the most artistic flower in the San Francisco Show, losing out only on a few points to a fifty dollar variety. It also won first honors at Los Angeles and New York. Stock limited. Price $\$ 3.00$ each 


\section{POMPON DAHLIAS}

These produce small compact flowers of perfect form and free blooming qualities. They are unequalled for cutting and garden display. Assorted varieties.

Price 35cts. each.

\section{CULTIVATION OF DAHLIAS}

$\infty$

Dahlias are easily grown, requiring no special soil, or treatment, to bring them to perfection. They love an open sunny location, but succeed in partial shade. Prepare the soil thoroughly by digging 12 to 18 inches deep, possibly in the fall and then again in the spring, before planting.

If the soil is poor, work in some well-rotted stable manure, or artificial fertilizer, but don't over do this.

Dig the holes 3 feet apart, and about 6 inches deep; drive a stout stake in each hole, and lay the tuber down flat, with the eyes to the stake, and cover with two to three inches of fine soil, leaving the hole to be filled after the plant comes up.

Plant any time between April 1st and June 15th.

When the plants have made their third set of leaves, cut out the top, to make them branch.

The most important thing from now on is hoeing and cultivating the soil, until the buds appear; then give the beds a good mulching of manure, to keep the ground moist; and water the plants thoroughly once or twice a week. tion.

If red spider or thrips appears, spray with a nicotine solu-

To have large blooms, it is absolutely necessary to disbud; that means, to break off all the side shoots on each stem, above the first or second set of leaves, leaving the sprouts near the base of each stem, so as to insure a new crop of blooms. Dahlias will continue to bloom, until the frost kills the tops; the tubers are dug and stored in a dry cellar or basement, cover them with dry sand, soil or sawdust, to keep from shriveling. Divide the tubers in thi spring after the eyes show plainly, being careful, that each tuber has an eye. Cover them again and keep dry until planted. 


$$
\begin{aligned}
& 2 y+2=0 \\
& 42+2
\end{aligned}
$$

$\frac{1}{2}+\frac{1}{2}$

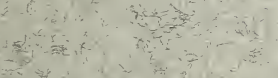


